\title{
Adverse Event Seriousness Date
}

National Cancer Institute

\section{Source}

National Cancer Institute. Adverse Event Seriousness Date. NCI Thesaurus. Code C93720.

The date (and time) on which the seriousness code was assigned to the adverse event. 